\title{
A Study Comparing Values of Serum Potassium Estimated by Colorimetric KIT Method with those Obtained by Direct and Indirect ION Selective Electrode Methods
}

\author{
Kusuma $\mathrm{KS}^{1}$, Vanitha Gowda $\mathrm{MN}^{2}$, Vasudha $\mathrm{KC}^{3}$, Radhika $\mathrm{K}^{4}$
}

\begin{abstract}
Introduction: Electrolyte abnormalities are treatable, but known to cause significant morbidity and mortality amongst the general population seeking health care services. The instruments with lon selective electrode (ISE) (direct or indirect ISE) are the reference methods which are unavailable in rural health care facilities.

Materials and methods: A prospective study was undertaken with 120 serum samples. Potassium was estimated using direct, indirect ionselective electrodes ISE and colorimeter. Statistical analysis was done using statistical package for social sciences (SPSS) version 17, NCSS 11 and MINITAB 18 software. A $p<0.05$ was considered statistically significant.

Results: A strongly positive correlation for potassium values between the instruments was noted. A simple linear regression analysis was done and a regression equation was derived for potassium values while comparing between the instruments. The Bland Altman analysis with $95 \%$ Limits of agreement was computed for potassium values between the instruments. It was well within the CLIA suggested target value \pm 0.5 $\mathrm{mmol} / \mathrm{L}$ for potassium.

Conclusion: The values of potassium estimated on the colorimeter are comparable with direct and indirect ISE in all the ranges. The derived regression equation calculates a predicted value for direct and indirect ISE using the values obtained on the colorimeter. This will be beneficial in identifying the altered levels of potassium in patients attending the peripheral health centers, use appropriate intervention and thereby reduce the morbidity and mortality with the use of a cost-effective and logistically feasible instrument viz., colorimeter.
\end{abstract}

Keywords: Bland Altman analysis, Colorimetry, Direct ISE, Indirect ISE, Potassium, Regression, Simple linear.

Indian Journal of Medical Biochemistry (2019): 10.5005/jp-journals-10054-0090

$\mathrm{P}$

otassium is the major intracellular cation located within the cells.

High intracellular concentrations are maintained by the $\mathrm{Na}+-\mathrm{K}+$ ATPase pump which is fuelled by oxidative energy and continually transports $\mathrm{K}^{+}$into the cell against the concentration gradient. Potassium is a very important mineral for the proper function of all cells, tissues, and organs in the human body. Potassium is crucial to heart function and plays a key role in skeletal and smooth muscle contraction, making it important for normal digestive and muscular function. Potassium is known to maintain the cell hydration and transmission of nerve impulses. ${ }^{1,2}$

Serum electrolytes are crucial parameters in critical care management. Hence, their accurate measurement is very important in making clinical decisions for treating patients. Over the years there has been a lot of progress in terms of use of newer methods for accurate and faster estimation of electrolytes in blood and serum. The earliest method for estimating serum potassium was by precipitation as chloroplatinate or cobaltinitrite, followed by titrimetric or colorimetric quantitation as described by Breh and Gaebler. ${ }^{1,3,4}$ Later Barnes, Richardson, Berry, and Hood devised the flame photometer to measure the low concentration of Potassium in solution. ${ }^{3}$ Atomic absorption spectrometry was established by Bunsen, Gustav and Kirchhoff for estimation of electrolytes in various biological fluids. However, most of the above methods have a long turnaround time, less sample throughput and are cumbersome to run. ${ }^{3}$ As serum potassium is a critical parameter, a newer method which could measure the electrolytes at a faster speed was developed and called as ion-selective electrodes (ISE) which specifically measured potassium in a short span of time. ${ }^{5}$ This is the standard reference method.

Several studies have been conducted so far comparing the various methods for estimation of serum sodium and

\author{
${ }^{1,4}$ Assistant Professor, ${ }^{2,3}$ Professor \\ ${ }^{1-3}$ Department of Biochemistry, Ramaiah Medical College, Bengaluru, \\ Karnataka, India \\ ${ }^{4}$ Department of Community Medicine, Ramaiah Medical College, \\ Bengaluru, Karnataka, India
}

Corresponding Author: Vanitha Gowda MN, Professor, Department of Biochemistry, Ramaiah Medical College, Bengaluru, Karnataka, India, e-mail: vanithasukesh@hotmail.com

How to cite this article: Kusuma KS, Gowda VMN, Vasudha KC, Radhika K. A Study Comparing Values of Serum Potassium Estimated by Colorimetric KIT Method with those Obtained by Direct and Indirect ION Selective Electrode Methods. Indian J Med Biochem 2019;23(1):221-225.

Source of support: Nil

Conflict of interest: None

Ethical Approval and Informed Consent: The ethical clearance was obtained from the Ethics Committee of the Medical College and written informed consent was taken from every patient or his relatives who came with the request for electrolytes.

potassium. ${ }^{6-9}$ A study showed that the analytical performance of the colorimetric method is acceptable for sodium and potassium while the analytical performance of flame photometry was not acceptable, keeping the ISE as the reference method. ${ }^{6}$ The study was done by Albert et al. compares the value of electrolytes measured by flame photometer against the direct and indirect ISE and indicates that there is a good agreement between the two methods and both can be used interchangeably. The studies compare the electrolyte values measured on an autoanalyzer and the arterial blood gas instrument. ${ }^{8,9}$ Both the studies suggest

(O) The Author(s). 2019 Open Access This article is distributed under the terms of the Creative Commons Attribution 4.0 International License (https://creativecommons. org/licenses/by-nc/4.0/), which permits unrestricted use, distribution, and non-commercial reproduction in any medium, provided you give appropriate credit to the original author(s) and the source, provide a link to the Creative Commons license, and indicate if changes were made. The Creative Commons Public Domain Dedication waiver (http://creativecommons.org/publicdomain/zero/1.0/) applies to the data made available in this article, unless otherwise stated. 
that the clinicians ought to be cautious while using the values interchangeably. ${ }^{8,9}$

The values of potassium measured on an ISE though accurate is expensive. Dyselectrolytemia is a treatable cause and must be detected in the early stages for better prognosis. The present study aims to compare serum potassium values estimated by a colorimetric kit method with the values obtained by direct and Indirect ISE methods. Colorimetric estimation is, and this simple instrument can be placed in any primary healthcare center (PHC).

\section{Materials AND Methods}

\section{Subjects/Materials}

- Time and place of study: The study period consisted of about 09 months from Aug 2016 to April 2017. It was conducted in the Clinical Chemistry Section of the Department of Laboratory Medicine in the hospital.

- Sample size with proper justification: A study carried out on "Comparison of ISE, flame emission spectrophotometer and colorimetry in the determination of serum electrolyte," has revealed the findings of an analysis of various methods. ${ }^{6}$ For ISE the potassium levels measured at different concentrations of 2, 4.5 and $8 \mathrm{mmoL} / \mathrm{L}$ were $1.84(0.05), 4.06(0.08)$ and $7.87(0.05)$ as compared to the potassium levels measured by colorimetric method with same concentrations were $1.78(0.04), 4.08(0.04)$ and 7.67 (0.05). Based on these findings, with an a- error of $5 \%$ and keeping the power of study as $80 \%$, the sample size requirement has been estimated to be around 115 samples.

- Study design: Prospective Study

\section{Inclusion and Exclusion Criteria}

Around 120 serum samples of patients aged between 1880 years of either gender, sent to the lab with a request for electrolyte estimation was included in the study. Samples which were hemolyzed, turbid, lipemic or hyperbilirubinemia were excluded.

\section{Methods}

The samples collected with a request for electrolytes were analyzed using Indirect ISE on Roche Cobas c501 chemistry analyzer (Roche Diagnostics GmbH, Mannheim, Germany) or using Direct ISE on Roche AVL 9180 (9180) electrolyte analyzer (Roche Diagnostics). Potassium was measured within 2 hours in the same serum sample using Sodium and Potassium Electrolyte Colorimetric Test kit obtained from Excel Diagnostics Pvt. Ltd. (Hyderabad, India).

Table 1: Reference ranges for serum sodium and potassium ${ }^{14}$

\begin{tabular}{llll}
\hline SI. No. & Analyte & $\begin{array}{l}\text { Reference ranges } \\
(\mathrm{mmol} / \mathrm{L})\end{array}$ & Groups \\
\hline 1. & Potassium $(\mathrm{K}+)$ & $3.5-5.1$ & Normokalemia \\
2. & Potassium $(\mathrm{K}+)$ & $<3.5$ & Hypokalemia \\
3. & Potassium $(\mathrm{K}+)$ & $>5.1$ & Hyperkalemia \\
\hline
\end{tabular}

Table 2: Mean and SD for sodium and potassium levels between C501, 9180 and colorimetry

\begin{tabular}{llll}
\hline & $\mathrm{n}$ & Mean & Std. deviation \\
\hline $\mathrm{K}^{+}$c501 & 100 & 4.18 & 0.88 \\
$\mathrm{~K}^{+}$colorimetry & 100 & 4.01 & 0.90 \\
$\mathrm{~K}^{+}$9180 & 35 & 4.26 & 1.17 \\
$\mathrm{~K}^{+}$colorimetry & 35 & 4.17 & 1.15 \\
\hline
\end{tabular}

\section{Principle}

Both direct and indirect ISE are based on potentiometry. There is a change in the electromotive force in a circuit between a measurement electrode and the reference electrode, as the selected ion interacts with the membrane of the ISE. ${ }^{10}$ Indirect ISE measures electrolytes by diluting the sample. The samples are diluted in ratios of 1:20 to $1: 349,10$ depending on the analytical system ( $9.7 \mu \mathrm{L}$ of sample + $291 \mu \mathrm{L}$ of ISE diluent in Roche Cobas C501). In the direct ISE method, the sample is presented to the electrodes without dilution. ${ }^{10,11}$ The estimation of potassium on a colorimeter was standardized using the standards provided in the kit. The estimation of potassium is by using the method of F.W William Sunderman published in 1958. ${ }^{2,12}$

\section{Statistical analysis and Results}

A prospective study for measuring and comparing potassium levels in serum was carried out on 120 samples selected by simple random sampling. The potassium $\left(\mathrm{K}^{+}\right)$was estimated on two different instruments Roche Cobas (c501) and Roche AVL 9180 (9180) by indirect ISE and direct ISE methods respectively. These values were compared with the potassium values measured by colorimetry. Data obtained was entered on MS Excel Sheet and the statistical analysis was done using SPSS version 17, NCSS 11 and MINITAB 18 Data Analysis Statistical software. A $p$ value $<0.05$ was considered as statistically significant.

The quantitative variables such as values of potassium were presented using descriptive statistics such as mean and SD. The correlation was computed for $\mathrm{K}^{+}$values, obtained using Pearson's correlation coefficient. Scatter plots were plotted to depict the same in the result analysis. Simple linear regression was done for $\mathrm{K}^{+}$values between the two instruments (C501 vs. Colorimetry and 9180 vs. Colorimetry). ${ }^{13}$ The linear regression equation was computed for $\mathrm{K}+$ values obtained by colorimeter to predict the values on c501 and 9180 and see whether they form a model of a good fit.

A total of 100 samples was compared between c501 and colorimetry, and 35 samples were compared between 9180 and colorimetry. The K+ values obtained from c501 and 9180 were further classified into three groups based on the normal reference ranges (Table 1). ${ }^{14}$ The values of potassium between the instruments are expressed in Mean and SD (Table 2). Pearson's correlation coefficient was calculated (Table 3). Simple linear regression analysis was done between the instruments for potassium. The unstandardized predicted values of $\mathrm{K}^{+}$for the above three groups was estimated between the instruments to check if they were comparable (Tables 4A to D). The graph for simple linear regression comparing the potassium value has been depicted in Figures 1 and 2. Agreement between the two instruments was assessed by the Bland Altman Analysis. Limit of the agreement was defined as difference \pm 1.96 * standard deviation (SD) (Table 5, and Figs 3 and 4)

\section{Discussion}

The most commonly used methods for determining serum potassium have been flame photometry and ion-selective potentiometry in most routine diagnostic laboratories. ${ }^{6}$ Measurements of these electrolytes by ISE have several practical advantages over flame emission spectrophotometry. Advantages

Table 3: Pearson's correlation between $\mathrm{K}+\mathrm{c} 501$ vs colorimetry and $\mathrm{K}+9180$ vs colorimetry

\begin{tabular}{llll}
\hline & $\mathrm{n}$ & $\mathrm{K}^{+}$on colorimetry & $p$ value \\
\hline $\mathrm{K}^{+}$on $\mathrm{c501}$ & 100 & 0.944 & $<0.001$ \\
$\mathrm{~K}^{+}$on 9180 & 35 & 0.959 & $<0.001$ \\
\hline
\end{tabular}


A Study Comparing Values of Serum Potassium Estimated by Colorimetric KIT Method

Table 4A: Regression-ANOVA with model summary, coefficients and residual statistics for $\mathrm{K}^{+}$values between c501 and colorimeter

\begin{tabular}{|c|c|c|c|c|c|c|}
\hline Source & $d f$ & Adjusted SS & Adjusted MS & Fvalue & $p$ value & Model Summary \\
\hline Regression & 1 & 66.179 & 66.179 & 1274.72 & $<0.001$ & \multirow{10}{*}{$\begin{array}{l}\text { R-square }-92.86 \% \\
\text { R-square } \\
\text { (Adj) }-92.79 \% \\
\text { R-square } \\
\text { (Pred) }-92.56 \% \\
\text { Std. error of the } \\
\text { estimate }-0.2279\end{array}$} \\
\hline \multicolumn{7}{|l|}{ R-square (Adj) -92.79\% } \\
\hline R-square (Pred) $-92.56 \%$ & & & & & & \\
\hline Std. error of the estimate -0.2279 & & & & & & \\
\hline Residual error & 98 & 5.088 & 0.0519 & & & \\
\hline Lack of fit & 68 & 3.820 & 0.0562 & 1.33 & 0.196 & \\
\hline Total & 99 & 71.267 & & & & \\
\hline Coefficents & & & & & & \\
\hline Term & & Coefficient & S E Coefficient & $\mathrm{t}$-value & $p$ value & \\
\hline Constant & & 0.510 & 0.105 & 4.84 & $<0.001$ & \\
\hline $\mathrm{K}+$ by colorimetry & & 0.9164 & 0.0257 & 35.70 & $<0.001$ & \\
\hline
\end{tabular}

Regression equation is: $\mathrm{K}^{+}$on $501=0.510+0.9164 \mathrm{~K}^{+}$bycolorimetry

Table 4B: Unstandardized predicted values and ANOVA for $\mathrm{K}^{+}$values between $\mathrm{C} 501$ and colorimeter

\begin{tabular}{|c|c|c|c|c|c|c|}
\hline \multirow[b]{2}{*}{ Colorimeter (reference ranges) } & \multirow[b]{2}{*}{$\mathrm{n}$} & \multirow[b]{2}{*}{ Mean } & \multirow[b]{2}{*}{$S D$} & \multirow[b]{2}{*}{ SE } & \multicolumn{2}{|c|}{$95 \%$ Cl for the Mean of c501 } \\
\hline & & & & & Lower bound & Upper bound \\
\hline $3.5-5.1 \mathrm{mmol} / \mathrm{L}$ & 69 & 4.23 & 0.421 & 0.051 & 4.13 & 4.34 \\
\hline$<3.5 \mathrm{mmol} / \mathrm{L}$ & 20 & 3.14 & 0.359 & 0.080 & 2.98 & 3.31 \\
\hline$>5.1 \mathrm{mmol} / \mathrm{L}$ & 11 & 5.76 & 0.493 & 0.149 & 5.43 & 6.09 \\
\hline Total & 100 & 4.18 & 0.818 & 0.082 & 4.02 & 4.35 \\
\hline \multicolumn{7}{|c|}{ ANOVA for Unstandardized predicted values } \\
\hline & SS & $d f$ & MS & $F$ & $p$ value & \\
\hline Between groups & 49.236 & 2 & 24.618 & 140.93 & $<0.001$ & \\
\hline Within groups & 16.944 & 97 & 0.175 & & & \\
\hline
\end{tabular}

Table 4C: Regression-ANOVA with model summary, coefficients and residual statistics for $\mathrm{K}^{+}$values between 9180 and colorimeter

\begin{tabular}{|c|c|c|c|c|c|c|}
\hline Source & $d f$ & Adjusted SS & Adjusted MS & Fvalue & $p$-value & Model Summary \\
\hline Regression & 1 & 40.923 & 40.923 & 520.92 & $<0.001$ & \multirow{8}{*}{$\begin{array}{l}\text { R- square- } 94.04 \% \\
\text { R-square (Adj)-93.86\% R-square } \\
\text { (Pred)-93.20\% } \\
\text { Std. error of the estimate- } 0.280\end{array}$} \\
\hline Residual error & 33 & 2.593 & 0.079 & & & \\
\hline Lack of fit & 30 & 2.453 & 0.082 & 1.76 & 0.360 & \\
\hline Total & 34 & 43.517 & & & & \\
\hline \multicolumn{6}{|l|}{ Coefficents } & \\
\hline Term & & Coefficient & SE coefficient & t-value & $p$-value & \\
\hline Constant & & 0.2715 & 0.181 & 1.50 & 0.143 & \\
\hline $\mathrm{K}^{+}$by colorimetry & & 0.9631 & 0.042 & 22.82 & $<0.001$ & \\
\hline
\end{tabular}

Regression equation is: $\mathrm{K}^{+}$on $501=0.510+0.9164 \mathrm{~K}^{+}$by colorimetry

Table 4D: Unstandardized predicted values and ANOVA for K+ values between 9180 and colorimeter

\begin{tabular}{|c|c|c|c|c|c|c|}
\hline \multirow[b]{2}{*}{ Colorimeter (reference ranges) } & \multirow[b]{2}{*}{$N$} & \multirow[b]{2}{*}{ Mean } & \multirow[b]{2}{*}{$S D$} & \multirow[b]{2}{*}{$S E$} & \multicolumn{2}{|c|}{$95 \%$ Cl for the mean of 9180} \\
\hline & & & & & Lower bound & Upper bound \\
\hline $3.5-5.1 \mathrm{mmol} / \mathrm{L}$ & 18 & 4.16 & 0.448 & 0.0106 & 3.94 & 4.38 \\
\hline$<3.5 \mathrm{mmol} / \mathrm{L}$ & 8 & 2.84 & 0.483 & 0.171 & 2.44 & 3.25 \\
\hline$>5.1 \mathrm{mmol} / \mathrm{L}$ & 11 & 5.71 & 0.269 & 0.089 & 5.51 & 5.92 \\
\hline Total & 100 & 4.26 & 1.097 & 0.185 & 3.88 & 4.64 \\
\hline \multicolumn{7}{|c|}{ ANOVA for unstandardized predicted values } \\
\hline & SS & $d f$ & MS & $F$ & $P$ & \\
\hline Between groups & 35.297 & 2 & 17.469 & 100.358 & $<0.001$ & \\
\hline Within groups & 5.627 & 32 & 0.176 & & & \\
\hline
\end{tabular}

of these electrodes include simultaneous and rapid determination, stable reagents and standby operations, non-requirement of external fuel and non-destruction of the sample. However, ISE's have certain technical difficulties such as instability or drift requiring frequent calibrations, and protein builds up on the electrodes requiring a change of electrodes in addition to the cost and complexity of integrating this techniques in to automated systems. ${ }^{6}$ Similarly, the flame photometer is a cumbersome 


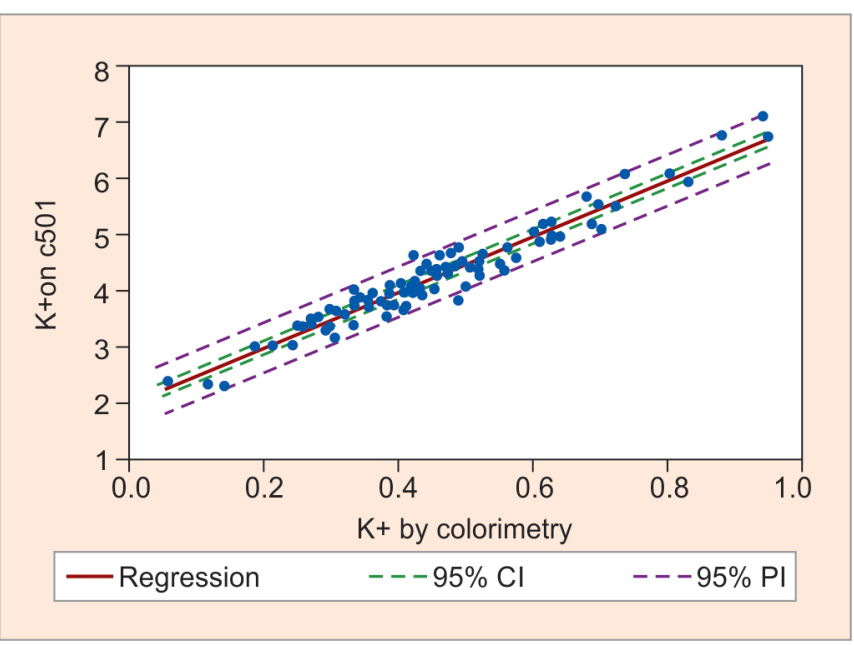

Fig. 1: Simple linear regression for $\mathrm{K}^{+}$values between c501 and colorimeter

Table 5: Bland Altman analysis

\begin{tabular}{|c|c|c|}
\hline & $\begin{array}{l}\text { Limits of agreement } \\
(95 \% \mathrm{Cl})\end{array}$ & Mean difference \\
\hline $\begin{array}{l}\mathrm{K}^{+} \mathrm{C} 501 \text { vs } \\
\text { colorimeter }\end{array}$ & $0.128-0.222 \mathrm{mmol} / \mathrm{L}$ & $0.175 \mathrm{mmol} / \mathrm{L}$ \\
\hline $\begin{array}{l}\mathrm{K}^{+} 9180 \text { vs } \\
\text { colorimeter }\end{array}$ & $0.023-0.215 \mathrm{mmol} / \mathrm{L}$ & $0.118 \mathrm{mmol} / \mathrm{L}$ \\
\hline
\end{tabular}

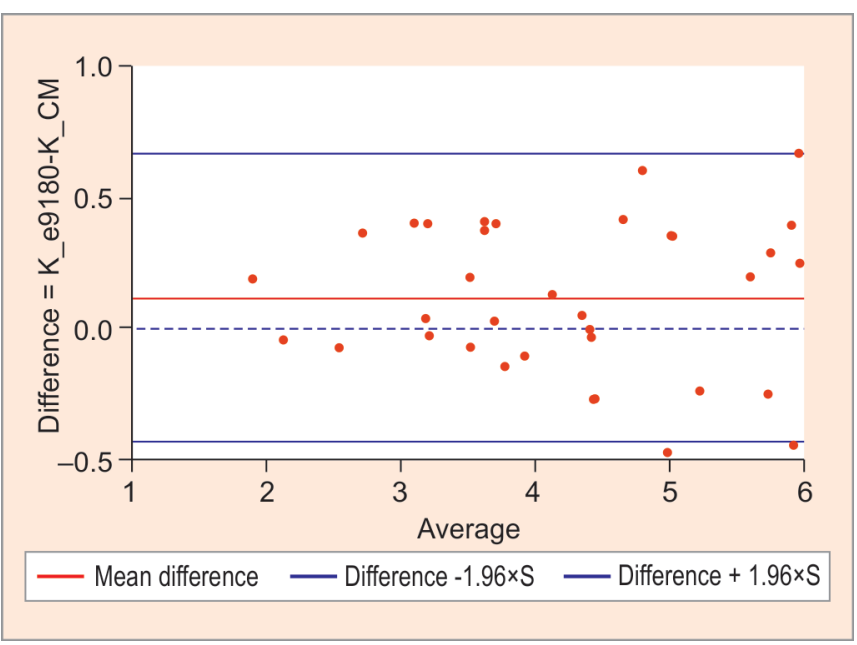

Fig. 3: Bland Altman plot for $\mathrm{K}^{+} \mathrm{c} 501$ vs colorimetry

process and requires a supply of fuel externally for estimation of electrolytes though it estimates electrolytes accurately. ${ }^{6}$

Serum electrolytes are the biochemical analytes commonly measured in patients who are either admitted in the critical care units or those attending the outpatient department. Dyselectrolytemia, a treatable cause is often missed in the peripheral health centers due to lack of advanced technologies and instrumentation. Though ISEs can give the results in a very short span of time, it is expensive and may not be logistically feasible to use in certain laboratory set-ups and not reachable for people from the low socioeconomic status. To overcome the above problems, the present study aimed at measuring potassium in a simple cost-effective instrument viz. colorimeter. The same was compared with the values obtained by the use of ISEs viz. the reference method.

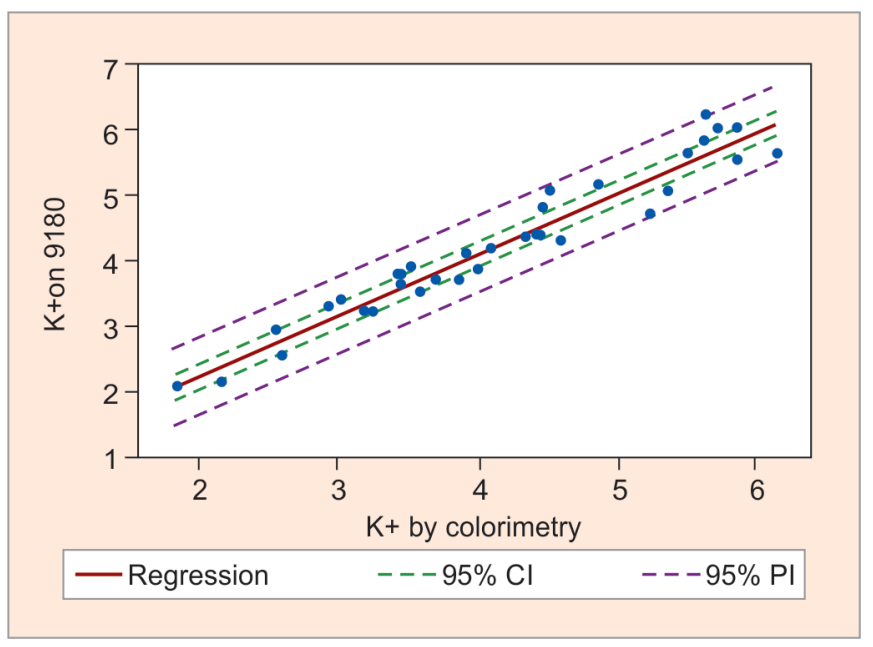

Fig. 2: Simple linear regression for $\mathrm{K}^{+}$values between 9180 and colorimeter

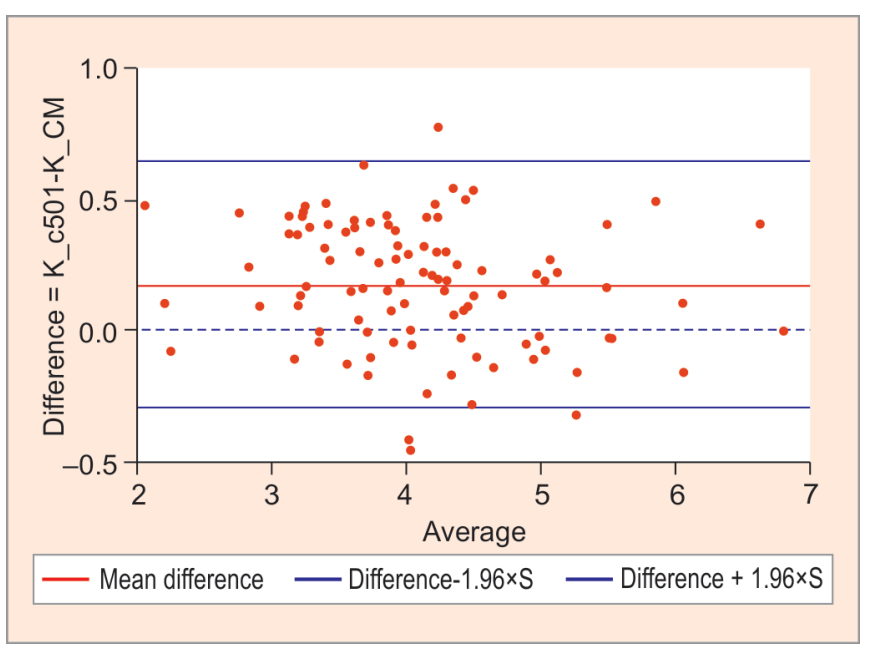

Fig. 4: Bland Altman plot for $\mathrm{K}^{+} 9180$ vs colorimetry

Table 3 shows that there is a strongly positive linear correlation between C501 and colorimeter and 9180 and colorimeter $(r=0.944$, $p<0.001$ and $r=0.959, p<0.001)$ for $\mathrm{K}^{+}$values. The ANOVA test applied in the linear regression model (Tables 4A and C) between c501 and colorimeter and 9180 and colorimeter for $\mathrm{K}^{+}$ values show an F-value $=1274.72$ and 520.92 with $p<0.001$. The Fvalue for samples which show lack of fit was 1.33 and 1.76 with $p \approx 0.196$ and 0.360 . This indicates that the potassium values are comparable between the instruments and the regression model is a good fit for the data obtained. The R-square is $92.86 \%$ and $94.04 \%$ which indicates that whatever the value of potassium measured on a colorimeter, a prediction of $\mathrm{K}^{+}$values up to $92.86 \%$ and $94.04 \%$ could be done with the help of the regression equations: $\mathrm{K}^{+}$on $\mathrm{c} 501=0.510+0.9164 \mathrm{~K}+$ by Colorimetry and $\mathrm{K}^{+}$on $9180=0.2715+0.9613 \mathrm{~K}+$ by colorimetry. In other words, for every $1 \mathrm{mmol} / \mathrm{L}$ increase in $\mathrm{K}^{+}$by colorimetry, the value of $\mathrm{K}+$ increases by $0.9164 \mathrm{mmol} / \mathrm{L}$ on $\mathrm{c} 501$ and $0.9631 \mathrm{mmol} / \mathrm{L}$ on 9180 , respectively. Tables $4 \mathrm{~B}$ and $\mathrm{D}$ show the values of unstandardized predicted $\mathrm{K}+$ values for $\mathrm{c} 501$ and 9180 in different reference ranges (Table 1), using the above prediction equation when values of $\mathrm{K}^{+}$by colorimetry were used. This indicates that the values of $\mathrm{K}^{+}$are comparable in all the groups between the two instruments/methods.

The colorimetric method for estimation of potassium is based on the measurement of turbidity of the reaction mixture containing 
sodium tetraphenylboron, alkaline EDTA, formaldehyde, and sample or standard containing potassium. ${ }^{2,12}$ Measurement of potassium is a single step method which involves the mixture of serum with the above reagent. This method is in good agreement with flame photometry and accurately measures potassium within the concentration of 2-7 mmol/L. It is also less cumbersome than the flame photometry. ${ }^{7}$ Care was taken while collecting serum samples to collect nonhemolyzed, nonlipemic and clear (non-turbid) samples as they are known to affect the results of serum potassium. ${ }^{10}$

The Bland Altman analysis done (Table 5) indicates that the mean difference of $\mathrm{K}+$ values was well within the CLIA suggested target value $\pm 0.5 \mathrm{mmol} / \mathrm{L} .{ }^{15}$ This indicates that the potassium values obtained using a colorimeter are as good as those obtained using an ion selective electrode (direct or indirect).

Hypokalemia and hyperkalemia are common disorders seen in hospitalized patients. ${ }^{16}$ Both are usually asymptomatic until severe and are often picked by the ECG changes. ${ }^{16}$ However, in some patients with severe hypokalemia, there are no ECG changes which mandate repeated potassium estimation in the patient for intervention. ${ }^{16}$ Hence a simple cost-effective instrument such as colorimeter can be used in a peripheral health center to measure potassium levels and thus intervene at appropriate times. This study will probably evolve a logistically feasible methodology/ instrument for electrolyte estimation in a cost-effective manner.

\section{LIMITATION OF THE STUDY}

The same samples could not be analyzed for potassium on both direct and indirect ISE instruments, and hence comparison between them could not be done.

\section{ConcLusion}

The values of potassium estimated by both the instruments (direct and indirect ISE) are comparable with the colorimeter in all the ranges. The regression equation has been derived for $\mathrm{K}+$ values between c501 and colorimeter and 9180 and colorimeter. This will help us in estimating the $\mathrm{K}+$ values on a colorimeter and derive a predicted value for $\mathrm{c} 501$ and 9180 which will help us in identifying the dyselectrolytemia in patients attending the peripheral health centers and thereby intervene and reduce the morbidity and mortality with cost-effective and logistically feasible instrument viz. colorimeter.

\section{ACKNOWLedgments}

Authors are extremely thankful for the funding received from the Minds United for Health Sciences and Humanity (Mysuru, India), an NGO which supports community-oriented research projects. They are also thankful to the technicians of the Clinical Chemistry Section, Department of Laboratory Medicine.

\section{References}

1. Richardson RW. Sodium and Potassium, Chapter V, Handbook of Non-pathologic variations in blood constituents. CRC Press 1994: 67-80

2. Sunderman FW Jr, Sunderman FW. The rapid colorimetric estimation of Potassium. Am J Clin Path 1959;29:95.

3. Sharmaa B and Sarmah D, A comparative evaluation of sodium and potassium measurement by Flame photometer and Direct ISE methods. International Journal of Health Sciences and Research 2013;3(6)59-65.

4. Breh $\mathrm{F}, \mathrm{Gaebler} \mathrm{OH}$. The determination of potassium in blood serum. J Biol Chem 1930,87:81-89.

5. Burnett RW, Covington AK, Fogh-Andersen N, et al. Recommendations for measurement of and convention for reporting sodium and potassium by lon Selective Electrodes in undiluted serum, plasma or whole blood. International Federation of Clinical Chemistry and Laboratory Medicine (IFCC). IFCC Scientific Division working group on selective electrodes. ClinChem Lab Med Oct 2000;38(10): 1065-1071.

6. Owierdu WKBA, Dzandu P, Amidu N. Comparison of Ion Selective Electrode, flame emission spectrophotometry and the colorimetric method in the determination of serum electrolytes. Ghana Journal of Allied Health Sciences May 2007:24-30

7. Albert V, Subramanian A, Rangarajan K, et al. Agreement of two different lab methods used to measure electrolytes. Journal of Lab. Physicians. Jul-Dec 2011;3(2):104-109.

8. Gupta S, Gupta AK, Singh K, et al. Are sodium and potassium result on arterial blood gas analyzer equivalent to those electrolyte analyzer? Indian J Crit Care Med 2016;20:233-237

9. Yılmaz S, Uysal HB, Avcil M, et al. Comparison of different methods for measurement of electrolytes in patients admitted to the ICU. Saudi Med J 2016;37(3)262-267.

10. Burtis CA, Ashwood ER, Bruns DE, eds. Tietz Textbook of Clinical Chemistry and Molecular Diagnostics, 4th Edition, St. Louis, MO: Elsevier Saunders. Chapter 27 Electrolyte and Blood Gases 2006:9831019.

11. Dimeski G, Badrick T, St John A. Ion selective electrodes (ISEs) and interferences-a review. Clinica Chimica Acta. 2010 Mar 2;411(56):309-317.

12. Terri A, Sesin P. Determination of potassium by using sodium tetraphenylboron. Am J Clin Path 1958;29:86-90.

13. Twomey PJ, Kroll MH. How to make use of linear regression and correlation in quantitative method comparison studies. Int J Clin Pract April 2008;62(4):529-538.

14. Bishop ML, Fody EP, Schoeff LE, eds, Clinical Chemistry-Principles, Techniques and Correlations. Seventh Edition. Chapter 16, Electrolytes written by George A Harwell, pp. 346-375.

15. USCLIA 2004. Standards and Certifications: Laboratory requirements (42CFR493). Regulations Part 493. Laboratory Requirements. Subpart I-Proficiency testing programs by specialty and subspecialty, Section 493.931-Routine Chemistry.

16. Viera AJ, Wouk N. Potassium Disorders: Hypokalemia and Hyperkalemia. Am Fam Physician 2015:92(6):487-495. 